\title{
CHANGES IN LIPID SYNTHESIS IN RAT ADIPOSE TISSUE DURING DEVELOPMENT
}

\author{
Muneo TsujIKAWA and Shuichi KIMURA ${ }^{1}$ \\ Laboratory of Nutrition, Faculty of Agriculture, \\ Tohoku University, Sendai 980, Japan
}

(Received March 21, 1980)

Summary Lipogenesis in rat adipose tissue during postnatal development has been studied by measuring the incorporation of labeled glucose into lipid in fat cells and the activities of certain enzymes which participate in lipogenesis. It was found that:

(1) Fatty acid synthesis from glucose is negligible in the suckling period. After weaning, it increases rapidly and reaches a plateau at the age of 10 weeks. (2) Insulin sensitivity is negligible in the suckling period. After weaning it rises and then declines. (3) Activities of ATP citrate lyase and acetyl CoA carboxylase are maintained at a low level in the suckling period. After weaning, these activities rise rapidly and then decline. (4) Weaning rats onto a high-fat diet showed decreases in glucose incorporation into fatty acids, insulin sensitivity, ATP citrate lyase activity and acetyl CoA carboxylase activity.

Keywords adipose tissue, lipogenesis, insulin sensitivity, development, weaning

Few investigations have been made on the changes in lipogenesis in adipose tissue during development, although changes in hepatic lipogenesis during development in rat and mouse have been studied (1-4). It has been supposed that not only the liver but also the adipose tissue is an important site of lipid synthesis in rat (5). In the present study, we have examined the incorporation of ${ }^{14} \mathrm{C}$-glucose into lipid in isolated cells of rat subcutaneous adipose tissue during development. The influence of a high-fat diet at weaning has been examined to determine the possible importance of diet in regulating lipogenesis in the developing rat. In addition, the activities of key enzymes of lipogenesis have been measured.

\section{MATERIALS AND METHODS}

Animals and diet. Wistar albino rats were used. Both males and females were killed at various ages up to the age of 2 weeks, whereas in experiments with rats

1 辻川宗男, 木村修一 
older than 2 weeks, males alone were killed. Litter sizes ranged from eight to ten young rats. Pups were removed from dams at the age of 3 weeks. Dams were then fed on the control diet described in Table 1 and pups were also fed on the same diet after weaning. In late weaning experiments, rats were fed on milk alone until 18 days of age and then fed on a high-fat diet, described in Table 1. The animals were killed at the same time of day by decapitation and subcutaneous fat pads were cut away immediately. The number of rats used was from five to seven in each group.

Table 1. Composition of experimental diets.

\begin{tabular}{|c|c|c|c|}
\hline Control diet & $(\%)$ & High-fat diet & $(\%)$ \\
\hline Starch & 69.0 & Starch & 12.5 \\
\hline Casein & 20.0 & Casein & 31.5 \\
\hline Soybean oil & 5.0 & Butter & 50.0 \\
\hline Salt mixture ${ }^{a}$ & 4.0 & Salt mixture ${ }^{\mathrm{a}}$ & 4.0 \\
\hline Water-soluble vitamin mixture ${ }^{a}$ & 1.0 & Water-soluble vitamin mixture ${ }^{a}$ & 1.0 \\
\hline Fat-soluble vitamin mixture ${ }^{b}$ & 1.0 & Fat-soluble vitamin mixture ${ }^{b}$ & 1.0 \\
\hline
\end{tabular}

${ }^{a}$ Composition is described by Harper (6). ${ }^{\mathrm{b}}$ One gram of fat-soluble vitamin mixture contains vitamin A, 1,000 I.U., vitamin E $10 \mathrm{mg}$, vitamin D 200 I.U., $p$-aminobenzoic. acid $10 \mathrm{mg}$, choline chloride $150 \mathrm{mg}$.

Preparation and incubation of fat cells. Adipocytes were isolated according to the method introduced by Rodbell (7). Fat pads were incubated at $37^{\circ} \mathrm{C}$ in $3 \mathrm{ml}$ of Krebs-Ringer bicarbonate buffer ( $\mathrm{pH}$ 7.4) containing per $\mathrm{ml}: 1 \mathrm{mg}$ glucose, $40 \mathrm{mg}$ bovine serum albumin fraction V (Armour Pharmaceutical Co.) and $3.3 \mathrm{mg}$ collagenase type 1 (Sigma Chemical Co.). After $1 \mathrm{hr}$, adipocytes were gently washed with Krebs-Ringer bicarbonate buffer and incubated at $37^{\circ} \mathrm{C}$ in $2 \mathrm{ml}$ of Krebs-Ringer bicarbonate buffer ( $\mathrm{pH}$ 7.4) containing per $\mathrm{ml}: 40 \mathrm{mg}$ bovine serum albumin, $1 \mathrm{mg}$ glucose and $0.25 \mu \mathrm{Ci}$ D-glucose- $1-{ }^{14} \mathrm{C}$ (specific activity 58 $\mathrm{mCi} / \mathrm{mmol}$, Radiochemical Centre, Amersham), with or without $1 \mathrm{mU}$ insulin (Sigma Chemical Co.). After $2 \mathrm{hr}$, lipids were extracted from fat cells and a part of the extract was hydrolyzed, the fatty acids subsequently being extracted. The radioactivity of the total lipid and fatty acids was counted in a liquid scintillation spectrometer. The radioactivity of glyceride-glycerol was calculated from the difference between total counts and those of the fatty acids after hydrolysis $(8)$. DNA was extracted according to the method of Schneider (9) and determined by the method of Ceriotti (10).

Enzyme assays. Adipose tissues were homogenized in a $0.25 \mathrm{M}$ sucrose solution. Homogenates were centrifuged at $105,000 \mathrm{~g}$ for $1 \mathrm{hr}$ and the supernatants were used for the assay of enzyme activities. ATP citrate lyase [EC 4.1.3.8] was assayed by the method of Kornacker (11) and acetyl CoA carboxylase [EC 6.4.1.2] by the method of Dakshinamurti (12). The protein content of the supernatants was 
determined by the method of Lowry-Folin (13).

\section{RESULTS}

Glucose incorporation into lipid of fat cells

In the absence of insulin in the medium, the incorporation of ${ }^{14} \mathrm{C}$-glucose into lipid was increased after weaning and was maintained at a high value. In the presence of insulin in the medium, the increase in synthesis of lipid was negligible at 2 weeks and about $200 \%$ at 5 weeks. Thereafter it fell to about $60 \%$ by the age of 10 weeks (Fig. 1). The incorporation of ${ }^{14} \mathrm{C}$-glucose into glyceride-glycerol after

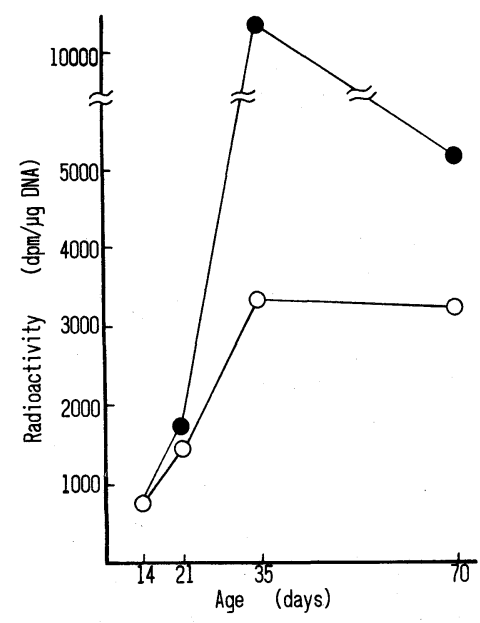

Fig. 1. Incorporation of ${ }^{14} \mathrm{C}$-glucose into lipid of fat cells during development. $\bigcirc$, no insulin; $\bullet$, insulin $1 \mathrm{mU} / \mathrm{ml}$.

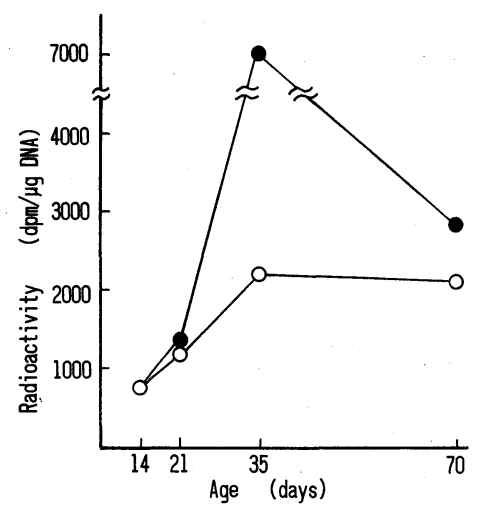

Fig. 2. Incorporation of ${ }^{14} \mathrm{C}$-glucose into glyceride-glycerol of fat cells during develoment. $\bigcirc$, no insulin; $\bullet$, insulin $1 \mathrm{mU} / \mathrm{ml}$. 
weaning rose about threefold over that in the suckling period (Fig. 2). The rate of incorporation of ${ }^{14} \mathrm{C}$-glucose into glyceride-fatty acids was negligible at 2 weeks, but rose rapidly after weaning (Fig. 3).

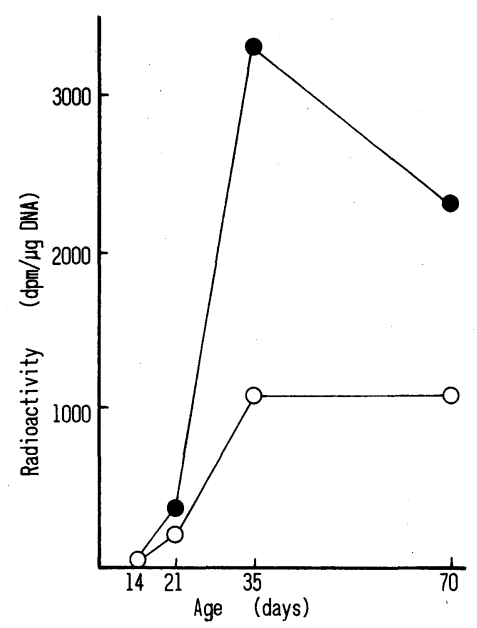

Fig. 3. Incorporation of ${ }^{14} \mathrm{C}$-glucose into glyceride-fatty acids of fat cells during development. $\bigcirc$, no insulin; $\bullet$, insulin $1 \mathrm{mU} / \mathrm{ml}$.

\section{Late weaning experiments}

The rise in the insulin sensitivity, the increased capacity for fatty acid synthesis and the increased incorporation of ${ }^{14} \mathrm{C}$-glucose into glyceride-glycerol after weaning were thought to be due to the change to the high-carbohydrate diet (solid diet) from the high-fat diet (milk diet). To test this possibility, rats were weaned onto an artificial milk diet and the incorporation of ${ }^{14} \mathrm{C}$-glucose into lipid was

Table 2. Effect of diet on incorporation of ${ }^{14} \mathrm{C}$-glucose into lipid of fat cells in 35-day-old rats.

\begin{tabular}{|c|c|c|c|c|c|}
\hline Group & Insulin & $\begin{array}{c}\text { Total lipid } \\
(\mathrm{dpm} / \mu \mathrm{g} \text { DNA })\end{array}$ & $\%$ increase & $\begin{array}{c}\text { Glyceride- } \\
\text { fatty acids } \\
(\mathrm{dpm} / \mu \mathrm{g} \mathrm{DNA})\end{array}$ & $\begin{array}{c}\text { Glyceride- } \\
\text { glycerol } \\
(\mathrm{dpm} / \mu \mathrm{g} \text { DNA })\end{array}$ \\
\hline Control diet & - & $\begin{array}{c}3,297 \pm 473 \\
10,328 \pm 4,753\end{array}$ & 187 & $\begin{array}{l}1,075 \pm 200 \\
3,307 \pm 1,320\end{array}$ & $\begin{array}{l}2,223 \pm 328 \\
7,021 \pm 3,442\end{array}$ \\
\hline High-fat diet & $\begin{array}{l}- \\
+\end{array}$ & $\begin{array}{l}2,039 \pm 179^{*} \\
2,497 \pm 274\end{array}$ & 24 & $\begin{array}{l}31 \pm 15^{* *} \\
24 \pm 15\end{array}$ & $\begin{array}{l}2,008 \pm 170 \\
2,473 \pm 272\end{array}$ \\
\hline
\end{tabular}

Each value represents mean \pm S.E.M. for 6 rats. Significantly different from control diet: ${ }^{*} p<0.05,{ }^{* *} p<0.01$. 
measured at the age of 5 weeks (Table 2). When animals were fed on an artificial milk diet, the rise in the insulin sensitivity was $24 \%$, which was lower than that of the control group, but not as low as that of 2-week-old rats fed on milk alone. No significant difference was noted between glucose incorporation into glycerideglycerol on the control diet and that on the high-fat diet. Labeled glucose was incorporated into fatty acids to a slight degree on the high-fat diet.

\section{Acetyl-CoA carboxylase activity}

The activity of acetyl CoA carboxylase was very low in newborn rats. The low activity was maintained throughout the suckling period, but after weaning a more than tenfold increase in the activity rapidly took place. Thereafter the activity declined abruptly (Fig. 4).

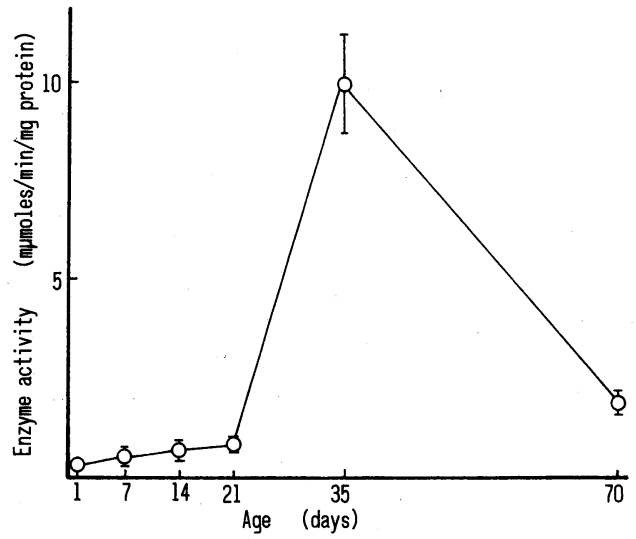

Fig. 4. Acetyl CoA carboxylase activity in adipose tissues during development. Each point represents mean \pm S.E.M. for 6 rats.

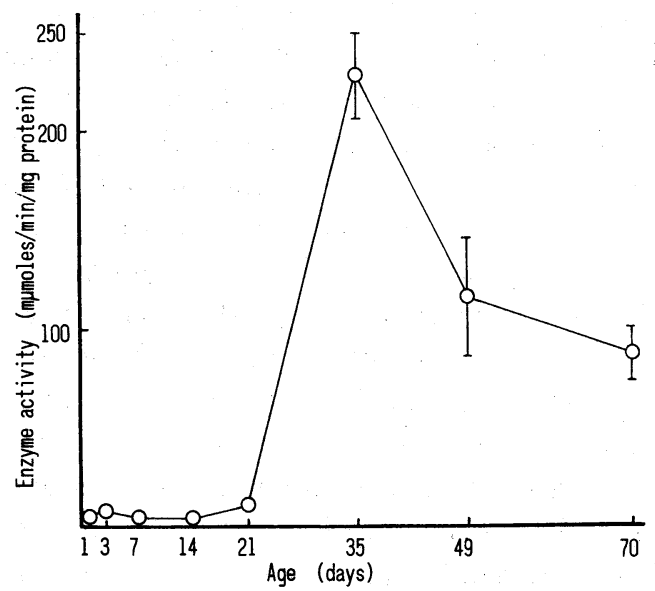

Fig. 5. ATP citrate lyase activity in adipose tissues during development. Each point represents mean \pm S.E.M. for 6 rats. 


\section{ATP citrate lyase activity}

The activity of ATP citrate lyase fell to some degree throughout the suckling period. After weaning, a more than twentyfold increase in the activity was observed. Thereafter the activity declined, the value attained at 10 weeks being about half that at 5 weeks (Fig. 5).

\section{Effect of late weaning on enzyme activities}

The rise in the activities of enzymes concerned with lipogenesis after weaning was inhibited when animals were weaned onto the high-fat diet. The activity of ATP citrate lyase on the high-fat diet was less than $5 \%$ of that on the control diet and the activity of acetyl CoA carboxylase on the high-fat diet was less than $10 \%$ (Table 3).

Table 3. Effect of diet on enzyme activities of adipose tissues in 35-day-old rats.

\begin{tabular}{ccc}
\hline Group & $\begin{array}{c}\text { Acetyl CoA carboxylase } \\
(\mathrm{nmol} / \mathrm{min} / \mathrm{mg} \text { protein })\end{array}$ & $\begin{array}{c}\text { ATP citrate lyase } \\
(\mathrm{nmol} / \mathrm{min} / \mathrm{mg} \text { protein })\end{array}$ \\
\hline Control diet & $9.94 \pm 1.24$ & $227.8 \pm 21.7$ \\
High-fat diet & $0.71 \pm 0.09^{*}$ & $8.1 \pm 1.0^{*}$ \\
\hline
\end{tabular}

Each value represents mean \pm S.E.M. for 6 rats. Significantly different from control diet: ${ }^{*} p<0.01$.

\section{DISCUSSION}

A rapid increase in insulin sensitivity, increased capacity for fatty acid synthesis and increased incorporation of ${ }^{14} \mathrm{C}$-glucose into glyceride-glycerol in fat cells were observed after weaning. The results of the experiments of late weaning suggest that the rises in insulin sensitivity and fatty acid synthesis are largely due to the change from a high-fat to a low-fat diet. The decline in insulin sensitivity on the high-fat diet is similar to that found by Tepperman (14). It is likely that this decrease is target organ regulation brought about by the qualitative change in diet. Insulin sensitivity on the high-fat diet, however, was higher than that found at the age of 2 weeks, so that it is likely that factors other than the fat content of the diet are involved. Since the insulin sensitivity of fat cells from rats during the suckling period is negligible, there should be little regulation in membrane transport of sugar and lipogenesis by insulin. Accordingly, this may be one of the causes of the low rate of glucose utilization in the suckling rats (15). Insulin sensitivity in adult animals was lower than that at the age of 5 weeks. Previous studies have indicated the possibility that the intracellular accumulation of a large amount of fat has an influence on the insulin receptor and glucose transport (16-18).

In the high-fat group, the major part of the glucose incorporated into lipid 
was converted to glyceride-glycerol. In the adipose tissue, glycerol formed from lipolysis is not reesterified. This is, therefore, considered to mean that the small amounts of glucose available in the high-fat diet are shunted into the production of $\alpha$-glycerol phosphate.

Three periods of change in the activities of acetyl CoA carboxylase and ATP citrate lyase during development may be distinguished: the low level during the suckling period, the sharp rise after weaning and the decline towards maturity. The late weaning experiments suggested that the sharp rise in the activities of both enzymes after weaning is perhaps due to the change of diet. Since the diet is constant from weaning to maturity, a change in nutrients cannot be invoked to explain the fall in enzyme activities during the period of maturity. It is thought that the fall in insulin sensitivity in adult animals induces the decline in glucose uptake. Thus it is possible that the fall in enzyme activities is due to the decline of the induction effect by glucose (19).

\section{REFERENCES}

1) Taylor, C. B., Bailey, E., and Bartley, W. (1967): Changes in hepatic lipogenesis during development of the rat. Biochem. J., 105, 717-722.

2) Ballard, F. J., and Hanson, R. W. (1967): Changes in lipid synthesis in rat liver during development. Biochem. J., 102, 952-958.

3) Lockwood, E. A., Bailey, E., and Taylor, C. B. (1970): Factors involved in changes in hepatic lipogenesis during development of the rat. Biochem. J., 118, 115-162.

4) Smith, S., and Abraham, S. (1970): Fatty acid synthesis in developing mouse liver. Archs Biochem. Biophys., 136, 112-121.

5) Shrago, E., Glennon, J. A., and Gordon, E. S. (1971): Comparative aspects of lipogenesis in mammalian tissues. Metabolism, 20, 54-62.

6) Harper, A. E. (1959): Amino acid balance and inbalance. J. Nutr., 68, 405-418.

7) Rodbell, M. (1964): Metabolism of isolated fat cells. J. Biol. Chem., 239, 375-380.

8) Bray, G. A. (1969): Effect of diet and triiodothyronine on the activity of glycerol-3phosphate dehydrogenase and on the metabolism of glucose and pyruvate by adipose. tissue of obese patients. J. Clin. Invest., 48, 1413-1422.

9) Schneider, W. C. (1946): Phosphorus compounds in animal tissues. J. Biol. Chem., 164, 747-751.

10) Ceriotti, G. (1952): A microchemical determination of deoxyribonucleic acid. J. Biol. Chem., 198, 297-303.

11) Kornacker, M. S., and Ball, E. G. (1965): Citrate cleavage in adipose tissue. Proc. Natl. Acad. Sci. U.S.A., 54, 899-904.

12) Dakshinamurti, K., and Desjardins, P. R. (1969): Acetyl-CoA carboxylase from rat adipose tissue. Biochim. Biophys. Acta, 176, 221-229.

13) Lowry, O. H., Rosebrough, N. J., Farr, A. L., and Randall, R. J. (1951): Protein measurement with the Folin phenol reagent. J. Biol. Chem., 193, 265-275.

14) Ip, C., Tepperman, H. M., Holohan, P., and Tepperman, J. (1976): Insulin binding and insulin response of adipocytes from rats adapted to fat feeding. J. Lipid Res., 17, 588-599.

15) Hahn, P. (1966): Utilization of nutrients during postnatal development. Pergamon,

Vol. 26, No. 4, 1980 
Oxford, pp. 76-83.

16) Hansen, F. M., Nielsen, J. H., and Gliemann, J, (1974): The influence of body weight and cell size on lipogenesis and lipolysis of isolated rat fat cells. Eur. J. Clin. Invest., 4, 411-418.

17) Girolamo, M. D., and Rudman, D. (1968): Variations in glucose metabolism and sensitivity to insulin of the rat's adipose tissue, in relation to age and body weight. Endocrinology, 82, 1133-1141.

18) Salans, L. B., and Dougherty, J. W. (1971): The effect of insulin upon glucose metabolism by adipose cells of different size. J. Clin. Invest., 50, 1399-1410.

19) Takeda, Y., Inoue, H., Honjo, K., Tanioka, H., and Daikuhara, Y. (1967): Dietary response of various key enzymes related to glucose metabolism in normal and diabetic rat liver. Biochim. Biophys. Acta, 136, 214-222. 